\title{
Bernd Fischer
}

\section{ALBANIAN NATIONALISM AND ALBANIAN INDEPENDENCE}

DOI: $10.2478 /$ seeur-2014-0005

One of the most welcome recent developments among Albanian historians and historians of Albania is a general reevaluation of critical events and periods in Albanian history, periods traditionally viewed through a generally accepted nationalist narrative not often challenged. This narrative, encouraged by political actors and most Albanian historians, was reinforced with the collapse of communism in 1991 and the occasion of various celebrated milestones in Albanian history. ${ }^{1}$ One such process subject to reevaluation is the rise of Albanian nationalism, leading to the London Conference of Ambassador's confirmation of Albanian independence during the Balkan Wars of 1912-1913.

The traditional narrative accepted by most Albanian scholars, as well as some prominent western scholars of Albanian topics, was a narrative of struggle to free Albania from the oppressors which included all neighbors but concentrated particularly on the Ottomans who took control of Albanian lands beginning in the 15 th century. ${ }^{2}$ Some more nationalist minded historians suggest that the struggle for freedom and independence dates as far back as 15th century, the era of the Albanian national hero Skanderbeg and progressed in linear fashion from that day. But virtually all Albanian historians believe that at the minimum, progressive political nationalism developed slowly in the 19th century, and then was given considerable impetus by the Eastern Crisis which saw traditional Albanian lands handed over to the Montenegins as part

1 Much of this was politically driven by the moderately nationalist regime of Sali Berisha although Berisha must be given credit for supporting a program which sent Albanian historians abroad to find relevant material in foreign archives and bring this material home to share with colleagues.

2 For an example of this narrative see Stefanaq Pollo and Arben Puto, The History of Albania, (London: Routledge and Kegan Paul, 1981). 
of a Great Power bargain. We are told that from this point a determined struggle for independence by single-minded nationalists/patriots with the support of a considerable percentage of the population developed rapidly. Indeed the more extreme official histories, particularly those from the Socialist period which are still often repeated today, ${ }^{3}$ argue that substantial popular gatherings supported the nationalists/patriots and that on the eve of the Balkan Wars, a vast movement demanding independence arose across Albania, demonstrating the remarkable level of political maturity the masses had achieved. ${ }^{4}$ While independence and the creation of the nation-state were inevitable in this view, the Balkan Wars and the London Conference of Ambassadors provided the occasion for the glorious moment.

This rather narrow view overlooks many important contributory factors which must be considered when examining the creation of Albanian nationalism and independence. These include, but are not limited to, four important factors most of which were little impacted by actual developments on the ground in Albania. First we have the slow cultural revival among the Italo-Albanians, or Arberesh, in southern Italy. Next we have the political, economic and cultural rivalry between Italy and Austria-Hungary for dominance of the strategically important Albanian lands. The third factor, which finally includes the activities of Albanians on the ground in the Albanian lands, is the work of a small vanguard of intellectuals who struggle to build a nation, but not necessarily a state. Finally, we will briefly consider what is likely the most important factor in the actual creation of the Albanian state, the London Conference of Ambassadors following the Balkan Wars.

It is perhaps unusual that the first spark of Albanian cultural nationalism developed not within Albania itself but among the Albanian diaspora in southern Italy, among the Arberesh, the descendents of those Albanian who fled the Ottoman Empire following the defeat of the Albanian national hero Skanderbeg in the 15th century. A brief examination of 19th century Albanian nationalism, however, puts this development in context. Albanian nationalism was not nearly as well developed as the nationalisms of the rest of the Balkans for some relatively clear reasons, stemming from both obstacles generated by conscious Ottoman policy as well as some positive Ottoman reinforcement.

Albanians lacked many of the necessary preconditions generally associated with unity, including an advanced civilization based upon a developed

3 For an excellent discussion of this phenomenon see James Pettifer, "The Heroic Image in Albanian Historiography." Accessed January 19, 2014, www.professorjamespettifer.com

4 Pollo and Puto, The History of Albania, pp. 139-140. 
educational structure. There was no advanced centralization and a lack of an infrastructure to provide one. The literacy rate at the end of the nineteenth century was the lowest in the Balkans and there was no proper national education system. Despite the requirements of the Tanzimat reforms which recognized the right of primary education in national languages in the Ottoman Empire, only a few Catholic schools in the north actually taught in the Albanian language. ${ }^{5}$ The few state schools that did exist used Turkish, and the Greek schools in the south, run by the Orthodox clergy of course taught in Greek. Albanians also lacked linguistic unity being divided between the Tosk and Geg dialects and being without a standard literary language.

Indeed, Albania was burdened with different levels of civilization, including the mountain clans in the north, the feudal aristocrats in the south and the more educated and urbanized population of the Orthodox and Catholic fringes. Religious division added another challenge since by the 19th century Albanians were divided into four principal faiths. With the Turkish invasions of the 15th century, Orthodox and Catholic Albanians converted to Islam in large numbers, with most adhering to the conservative Sunni sect, although Bektashism, which fused a number of Sunni, Shia and Sufi concepts, made considerable inroads in the center and the south. This religious diversity deprived Albanians of one the important catalysts for nationalism in the Balkans. From a social and economic standpoint there was no leadership of a self-conscious class. The Middle Class was tiny and the economy was primitive.

Again unlike most of the rest of the Balkan peoples, the Albanians had a less well developed medieval hero mythology. While Skenderbeg ultimately assumed that role, he pales in comparison to Dushan of Serbia and Boris of Bulgaria as a unifying symbol. There was little foreign intellectual stimulus and foreign support. Unlike most of the rest of the Balkan peoples who relied upon powerful advocates, the interest which Austria-Hungary and Italy showed in the Albanians was often superficial and changeable. ${ }^{6}$ Neither provided the type of sustained support which Serbia could count on, and still takes for granted, from Russia.

As the Ottomans began to understand the dangers of nationalism, they instituted policies which put further obstacles in the way of Albanian unity,

5 Barbara Jelavich, History of the Balkans: Twentieth Century, (Cambridge: Cambridge University Press, 1983), p. 84.

6 see Bernd J. Fischer, "Aspects of the Austro-Hungarian/Italian Rivalry in relation to the Albanian National Renaissance," in Jusuf Bajraktari ed., Lidhja Shqiptare e Prizrenit, 1878-1881, Instituti i Historise, Prishtine, 2011. 
including a restrictive language policy and the division of Albanian speakers into four provinces. The Ottomans, though, also successfully presented themselves as the protectors of Albanian lands against Slavic and Greek encroachment and favored the Albanians in many ways. Except during times of revolt there was little official Ottoman oppression. The clans in the north were left with virtual autonomy, subject only to sporadic taxes and military draft requirements. Albanians were actively recruited for high-level administrative and military positions in the Ottoman Empire. Fully one-fifth of all Grand Viziers, some thirty of them, were Albanians. Abdul Hamid had a particular weakness for Albanians, his personal guard was made up of Albanians and he often commented that his empire depended on the Albanians and the Arabs. ${ }^{7}$

These and other factors slowed the development of a national consciousness among the Albanians. It is not surprising, then, that the first evidence of Albanian cultural nationalism appeared among the Arberesh in southern Italy, who were not subject to the restrictions of Ottoman officials and Greek prelates. Arberesh intellectuals, with the model of the Italian Risorgimento as encouragement, produced inspiring nationalist literature, and worked to systematize the Albanian language. The two most prominent early contributors working in the 1860s and 1870s included Demeario Camarada, who published a study of the Albanian language demonstrating its antiquity, and Girolamo de Rada who through poetry commemorated the Albanian struggle against the Turks. ${ }^{8}$ In the late 1880 s they united their efforts to sponsor two linguistic congresses, affording the Arberesh some international prominence and demonstrating their will to become involved in the affairs of the motherland. The second congress passed a comprehensive program to stabilize and legitimize the Albanian language, calling for a unified alphabet, the compilation of a dictionary, the foundation of an Albanian national society, and the opening of broad scale relations with Albanians in the motherland. ${ }^{9}$ These Italo-Albanians played an important role in encouraging the Albanian national movement. They mobilized public opinion and made the Albanian question known. Their work with language and folklore was a significant service to the national awakening.

7 George Gawrych, The Crescent and the Eagle, Ottoman Rule, Islam and the Albanians, (London: I.B. Tauris, 2006) pp. 82-83.

8 Leften Stavrianos, The Balkans since 1453, ( New York: Holt, Rinehart and Winston, 1965) p. 502.

9 Stavro Skendi, The Albanian National Awakening, (Princeton NJ: Princeton University Press, 1967), p. 221. 
The Italian Austro-Hungarian rivalry with regard to Albanian lands also constituted an important factor in the national awakening leading to independence. The respective motivation of the two states for involvement was very similar and had to do with Great Power rivalry in the age of new imperialism, as well protection of national interests. For both states Albanian lands were of particular significance because of the stretches of Adriatic coast opposite Italy. Italy had no suitable base for naval operations off its west coast, with Venice and Brindisi being considered insufficient for Italy's purposes. Italy coveted Vlora because of its bay and proximity to the Italian peninsula and could not afford to allow Austria-Hungary an advantage there. ${ }^{10}$ The Italians were also suspicious of growing Austro-Hungarian influence among Albanian Catholics, over which the Austrians had extracted a form of protectorate at the Congress of Berlin. Although the two states concluded a series of agreements broadly based on the principle of a reciprocal compensation for every advantage, territorial or otherwise, ${ }^{11}$ this did not preclude intense competition in various fields. The two states rushed to secure advantages through the sponsorship of shipping institutions, schools, post offices, welfare institutions, hospitals, banks, credit for railroad construction, among other methods of influence. ${ }^{12}$

The rivalry constituted an important contribution to the Albanian national awakening and ultimately Albanian independence. With their schools and other cultural contribution, the two states exposed many Albanians to new political/social/economic ideas and diverse cultures. Through their efforts in shipping and trade, as well as through study abroad programs, they exposed Albanians to the hitherto unknown outside world. The rivalry brought Albanians closer together physically by the building of roads and the planning of railroads. The rivalry also made Albanians more aware of their own interests and individuality.

The rivalry, then, was certainly important. But more important as a determining factor with regard to the national awakening and Albanian independence, were the efforts of a small vanguard of Albanian intellectuals who helped to lay the groundwork for a national consciousness. While traditional Albanian historiography sees these individuals as single minded nationalists who succeeded in instilling nationalism and a desire for independence in the masses, a new generation of historians has developed a

10 E.J.P. Dillion, "Albania," Contemporary Review, July 1914, p. 9.

11 Alfred Pribram, The Secret Treaties of Austria-Hungary, (Cambridge MA: Harvard University Press, 1920), p. 109.

12 Hans Dieter Schanderl, Die Albanienpolitik Osterreich-Ungarns und Italiens (Weisbaden: Otto Harrassowitz, 1971), p. 77. 
more sophisticated analysis. While the work of this new generation is broad ranging, in general, what emerges for the period under consideration here is an analysis of the interplay of cultural and political Albanianism, with Ottomanism and Islamism which, rather than being constantly in conflict are often in harmony. ${ }^{13}$ This still-developing scenario suggests that those who are today considered the principal nationalist heroes in the Albanian pantheon were more than just nationalists but were also, and perhaps not in contradiction, Ottoman intellectuals who believed that working for what they saw as the natural ethnic rights of Albanians was not just a means by which to encourage Albanian enlightenment and to insure elite survival, but would also strengthen and sustain the Ottoman Empire.

The political spark for Albanian nationalism did not materialize until a powerful challenge to the Ottoman Empire, through the Eastern Crisis of 1875-78, threatened the detachment of Albanian inhabited lands. The movement among the Albanians was, in a way, reactionary in that it hoped to reestablish something which had been lost. Rather than a separatist movement, as found elsewhere is the Balkans, the Albanian political nationalist movement in the form of the League of Prizren, initially at least, fought against the dissolution of the Ottoman Empire. The League's founding platform was limited to regional issues and pledged to defend the Sultan and the territorial integrity of the Ottoman Empire. ${ }^{14}$ The Albanian nationalist Abdul Frasheri eventually expanded this limited agenda into a national reform program which sought the unity of all Albanian speaking peoples and autonomy within the empire. But his influence should not be overemphasized, there was much disunity in the League with different groups pursuing different agendas through various means. The Sultan initially saw this movement as a patriotic one and encouraged it, using it to reclaim some territorial losses. Once it had outlived its usefulness, and with the talk of autonomy encouraged by Abdul Frasheri, the Sultan imposed a military solution and crushed the league.

The years following the crisis were relatively quiet in the Albanian lands. The policy of Abdul Hamid slowly shifted to the encouragement of Islamism as a bulwark against secular nationalism, away from the Ottomanism of the Tanzimat period. While Ottomanism did not vanish, there was less official

13 Instrumental in the development of these categories and narrative is the work of George Gawrych, particularly his fine book The Crescent and the Eagle, Ottoman Rule, Islam and the Albanians, (London: I.B. Tauris, 2006).

14 Denis P. Hupchick, The Balkans: From Constantinople to Communism, (New York: Palgrave, 2002), p. 404. 
encouragement of it. Islamism as a way to build unity came to the fore. ${ }^{15}$ For the Albanians this new emphasis resulted in the introduction of a rather complex policy. Abdul Hamid clearly favored Albanians - he even spoke some Albanian. He saw them as much more of an asset than a liability. He understood how dependent Albanians were on the Ottoman state and yet also recognized their important to him. He even supported reforms and some would likely have been implemented had it not been for growing financial chaos in the empire. Abdul Hamid did, however, further integrate Albanians into imperial structures and increased his reliance on Albanians, who he referred to as his "iron barrier ${ }^{16 "}$ in the Balkans. This included personal protection as he expanded the role of Albanians in the palace guard. Albanians protected his residence at Yildiz, the parliament at Ciragan palace, as well as the most significant religious leaders. The commander of the guard to 1909 was an Albanian, and Albanians eventually outnumbered other groups in the rank and file as well as controlled a disproportionate number of top positions in the guard. Likewise there were many Albanians in the second imperial division, tasked with the protection of the capital. ${ }^{17}$

At the same time, Abdul Hamid continued the practice of co-opting local Albanian chiefs and expanded his reliance on influential families in the center and the south. Through these policies, Albanians were kept relatively quiet for thirty years. Despite this lull, however, Albania intellectuals did during those years experience a marked growth in sophistication of thought with regard to nationalism, thought which was certainly impacted by the empire's enhanced appreciation of the Albanians.

It is of value to briefly look at three of the most prominent of the contributors to pre-independence nationalism and some of their basic ideas, which generally combined being Ottoman with being Albanian. These were multi-identity elites who had been integrated, even assimilated into the Ottoman establishment, rather than monolithic single-minded patriots as they are sometimes portrayed.

All were of course elitist intellectuals who argued that the people were backward and needed to be educated and guided by them. All were influenced by French experience, indeed one even wrote his major works in French. While all were prolific writers let us concentrate on some of the positions which they took on the major national issues. One of the central goals of these

15 Gawrych, The Crescent and the Eagle, p. 78.

16 Ibid., p. 80.

17 Ibid. 
individuals, like many of their predecessors in the League of Prizren, was the preservation of the Ottoman Empire, although again as with the League there was much debate about how to save it. The first of the three, Pasho Vasa who died in 1892, will serve as a representative of the first generation of the Albanian nationalist movement. As a Catholic he was aware of the divisive nature of religion in Albania and hope to downplay it by publicizing the notion that the religion of Albanians was Albanianism, perhaps a bit of wishful thinking during his period. He was a politician and publicist as well as a highranking Ottoman official, serving as governor general of Lebanon from 1883 until his death. He argued for the position that all Albanians should be allowed to live in a single province and use their own language. He downplayed the call for autonomy, arguing that the Albanians were under-developed and not yet capable of self-government. He wrote about a paternalistic Ottoman state, something which Albanians had come to depend on, which sheltered the Albanians to the extent that a certain symbiosis has developed between the two. He saw the Ottoman government, of which he was an integral part, as the most illuminated part of society, something which should be nurtured and protected. He saw the Albanians as ready to do that, to defend the state and the sultan. ${ }^{18}$

Representative of the second generation of nationalist thinkers is Sami Frasheri who died 1904. Sami, brother of Abdul Frasheri, was one of the leading intellectual lights of the late Ottoman period and is remembered as a linguist and a journalist. His loyalties were even more complex than those of Vasa, having essentially a triple identity including Albanian, Turkish and Ottoman. But once again, his loyalties were essentially complementary and rarely in tension. As a linguist he wrote extensively about the Turkish language producing dictionaries and articles and his major contributions involved work in the standardization process of both Turkish and Albanian. He is perhaps best known, however, for his play Besa which he saw as an attempt to teach Ottomans about Albania. ${ }^{19}$ In his work on nationalism he wrote about the general and the specific Vatan (or motherland), in his case Ottomanism and Albanianism. ${ }^{20}$ He saw them joined by an umbilical cord, essentially nurturing each other. He saw the Albanians as an integral part of the Ottoman Muslim people. Again like Vasa he argued that Albanians should be unified into one province with their own language. With that increased cohesion and strength they would then be ready to more vigorously defend the

\footnotetext{
18 Artan Puto, "The Idea of the Nation during the Albanian National Movement, (18781912)" (Ph.D. diss., European University Institute, 2009), p. 301.

19 see Sami Frasheri, Besa, (Shkup: Vatra, 2002).

20 Gawyrch, The Crescent and the Eagle, p. 163.
} 
state and sultan. He, too, downplayed autonomy but at the end of his life, as it became increasingly clear that the empire might not survive, he became more politicized and ruminated on an Albanian state. ${ }^{21}$ Having lived and died in Istanbul, he was considered Turkish and Ottoman to the extent that his body was not returned to Albania until the 1950s.

Finally, as a representative of the third generation we have Ismail Kemal Bey who is often referred to as the father of Albanian independence. He, like Vasa, was an Ottoman politician and dignitary serving as a provincial administrator throughout the empire, the heir to a powerful Albanian family which had faithfully served the empire for centuries in consolidating its power in Albanian lands. He was an enthusiastic supporter of the early Tanizimat period which aimed to establish a somewhat more decentralized system in the empire, but his fundamental goal of saving the empire is clear throughout his writings. In his widely read memoirs he sets aside more space for an exploration of his devotion to the Ottoman Empire than to his homeland of Albania and its people. ${ }^{22}$ He described the Albanians as a noble savage community which required the protection of a benevolent Ottoman Empire. He saw the linking of Albania to the empire as a way of both strengthening Ottoman rule in the Balkans and preserving the Albanians as a separate and distinct peoples. Kemal refused to abandon the empire until it became clear that it could no longer offer the protection that the Albanians required. ${ }^{23}$ Like Vasa and Frasheri, Kemal concentrated on the creation of a nation, rather than the creation of a state.

But this slow formation of the intellectual foundation of a nation in Albania was quickly outpaced by geopolitical events in Europe and the empire. Abdul Hamid's repression and conservatism generated opposition, some of which led to the organization of the Committee of Union and Progress (CUP) dedicated to reform by any means, again in the hopes of strengthening the empire. The CUP understood the importance of Albanians in any future changes so consciously courted Albanian leaders. To that end, the initial CUP propaganda avoided specific attacks on Abdul Hamid himself, knowing the Albanians tended to view him in a positive light. But internal conditions in the empire continued to deteriorate with a food crisis in 1908 resulting in revolts even in Albania. Internationally, the Reval accords, seen by many as the government's inability to prevent foreign occupation of the empire's territory, galvanized the

21 Artan Puto, "The Idea of the Nation during the Albanian National Movement", p. 302.

22 see Sommerville Story ed., The Memoirs of Ismail Kemal bey, (London: Constable, 1920).

23 Artan Puto, "The Idea of the Nation during the Albanian National Movement", pp. 303 304. 
Committee to call for a general revolt. Albanian clans joined in with the cry "constitution and sultan," seeing their participation as a patriotic act resisting outside aggression.

The success of the revolution brought profound changes for at least literate Albanians. The removal of traditional restrictions led to a cultural revival generating a flood of literary societies, newspapers, journals, clubs of various sorts and schools which taught in the hitherto forbidden Albanian language. These unprecedented innovations came so quickly that many conservative Albanians were caught off-guard and objected to this rapid dismantling of the old status-quo. Some of these latter elements supported Abdul Hamid's counter revolution in 1909, which was principally the work of political opposition to the CUP, Moslem religious leaders, as well as some disaffected Albanian regiments. Like the cultural revival, the counter revolution resulted in some disunity among Albanian elites. While many progressive elements, including most of the patriotic clubs, objected to this attempted reverse of course, the counter revolution gained the support of many Albanian chieftains like Isa Boletin, who were tied to Abdul Hamid through position and favors. ${ }^{24}$ Indeed, even nationalists like Ismail Kemal called for respect for the new government of the Sultan. Each new action or event seemed to emphasize once again the continuing disunity among the Albanian elite rather than the monolithic unity claimed by nationalist writers. But soon CUP policy alienated various segments of Albanian society.

With the swift failure of the counter revolution, the CUP initiated a new harder policy in their efforts to modernize and save the empire. Abdul Hamid's goal of transforming the Albanians into one of the principal pillars of support for the empire in Europe based upon a reenergized Islamism was abandoned in favor of a revived Ottomanism based upon order and progress through centralization. This alienated traditional conservative Albanian tribes in the north, particularly following an attempt to arrest Isa Boletin for his support of Abdul Hamid. And those nationalists in the south who had opposed the counter revolution and had hoped that an expansive understanding of Ottomanism would include Albanianism, were alienated when they saw order and security take precedence over reform. ${ }^{25}$ Indeed, the CUP, surprised by the enthusiasm generated by the Albanian cultural awakening, began to view it as a threat to Ottomanism and moved against it.

The result was a series of rolling uprising originating from local disturbances in 1909 which continued in one form or another until the onset

24 Gawrych, The Crescent and the Eagle, p. 163.

25 Ibid., p. 170. 
of the Balkan Wars, principally in the north but also in scattered areas of the center and south. Not included in these revolts were large parts of the center, which were somewhat less developed, and parts of the south, not threatened by Greeks or Serbs, which did not participate until 1912. ${ }^{26}$ The diverse group of rebels issued diverse demands mostly local in character. The conservatives were principally interested in the return of traditional privileges, while the progressives demanded the removal of new restrictions on the Albanian cultural awakening and other modern reforms. But there were also nationalist demands, centered usually on unity of the Albanians. Some, but not all, demanded autonomy as well while none went as far as independence.

The Turkish government was surprised by the rapid spread of these uprisings and became increasing desperate because of mounting additional challenges. The CUP was forced first to negotiate and then to offer a series of compromises to the Albanians. In August 1911 the CUP agreed to the Tepedelen agreement, concluded principally with the southern leaders, which promised the opening of schools and the teaching of the Albanian language, the assignment of officials with local knowledge, the restriction of military service to Albanian provinces, and a reduction in taxes. ${ }^{27}$ But the increasing power of the CUP and its underlying emphasis on centralization worried Albanian nationalists who began talking about encouraging a general revolt. With the strengthening of the CUP as a result of a rigged election in February 1912 new clashes in Kosovo occurred and the Albanians presented new demands, still short of autonomy. By July Albanian rebels had taken control of most of Kosovo, and with unrest in the Ottoman army the government was once again forced into negotiations with the Kosovar Albanians representing both the tribes and the towns. Hasan Bey Pristine, acting as representative, presented fourteen demands which became known as his fourteen points. The government eventually conceded to twelve of the demands which addressed both traditional privileges, such as respect for customary law and the right to carry guns, as well as some national goals like the use of the Albanian language in state schools. ${ }^{28}$ The CUP offer once again split the Albanians with some of the tribes pushing for the return of Abdul Hamid while the representatives of the towns insisted that the offer be accepted. The latter prevailed and as a result, while still short of unity and autonomy, significant gains were made.

These gains, however, in part helped precipitate the Balkan Wars which ultimately saw Albania created as an independent state but saw Kosovar

26 Stavrianos, The Balkans since 1453, p. 507.

27 Gawrych, The Crescent and the Eagle, p. 190.

28 Ibid., p. 195. 
Albanians trade the relatively benign Ottoman rule for a much harsher Serbian one. Albanian developments provided a greater sense of urgency for military action on the part of surrounding Balkan states which feared that unity and a stronger sense of national identity under the protection of the Ottoman Empire among the Albanians would weaken their claims. The Balkan states were also encouraged by the empire's inability to deal effectively with Albanian rebels as this indicated increasing Ottoman military weakness. ${ }^{29}$

When the Balkan Wars began, some Ottoman commanders expressed concern about Albanian loyalties but the majority of Albanians fought on the side of the Ottomans as usual. Ottoman military failure saw some Albanians desert and simply return home. With the defeat of the Ottomans only a matter of time, Albanian leaders were desperate to prevent the loss of Albanian lands. Ismail Kemal recognized that this could only be guaranteed with the support of the west since the Ottomans were now prostrate. Following assurances of support from both the Austrians and the Italians, Kemal returned to Albania in November 1912 summoned a makeshift congress made up primarily of town representatives from the south and proclaimed Albanian independence. The Balkan states at war naturally ignored the declaration but the London Conference of Ambassadors held in London in December to deal with the results of the war, supported the Albanians. Initially the conference would only go so far as to support autonomy under the Ottomans with Great Power protection, but once the empire lost Macedonia and then was removed from Europe entirely, Albania and the empire were without contiguous frontiers. With autonomy no longer a practical option, the conference support independence, an independence granted essentially by default. As Kemal makes clear in his memoirs, the proclamation of independence was dictated by circumstances resulting from the Balkan Wars, which rendered impossible the continued attachment of Albanians to the empire. Independence was the result of the withdrawal of the Ottomans and their armies from the Balkans, rather than an expression of the desire and will of the majority of Albanian speaking people. Since even the Albanian intellectual elites at the time were rarely supportive of the concept of an independent Albania, it is perhaps not surprising that when independence finally came on the eve of the First World War, it came as a result of outside forces and events beyond the control, or even the influence, of the Albanians themselves.

National independence is often the culmination of a national movement. In the Albanian case, independence, required by the Balkan Wars, was in a way the beginning of the national movement. Independence saw the creation of a state but not a nation. Independence certainly spurred Albanian

29 Stevan K. Pavlowitch, A History of the Balkans, 1804-1945. (London: Longman, 1999), p. 197. 
intellectual nationalism along, particularly since the state that was recognized by the London Conference of Ambassador and confirmed by the Peace of Paris, was severely restricted territorially and included no more than $50 \%$ of all Albanian speaking people in the Balkans. The creation and confirmation of the Albanian state created a focal point for this growing nationalism, but perhaps more importantly, it provided negative reinforcement for the national movement. The resulting truncated state was met with considerable disappointment on the part of Albanian nationalists, who felt that they had been misled by the talk of justice and self-determination which served as themes for the negotiators at the Peace of Paris. There was a feeling among Albanian nationalists that placing trust in the Great Powers was to believe in a "broken reed." 30 Sentiments of this sort increasingly led Albanian intellectuals to the conclusion that they would have to rely on their own limited resources to secure their own interests. It was sentiments of this sort which led to the convening of the Congress of Lushnje in 1920, which did much to create the structure of the new state.

Albanian nationalism, then, was encouraged by a combination of factors, including the cultural revival among the Arberesh of southern Italy, the rivalry between Italy and Austria-Hungary for influence and control of the eastern shores of the Adriatic, the political nationalism cultivated by a small vanguard of Albanian intellectuals in the empire, and the negative reinforcement provided by the London Conference of Ambassadors and the Peace of Paris. But even following the declaration of independence and its confirmation, the Albanian national movement remained essentially an intellectual movement, the growing attachment of intellectuals to the nationalist ideology, rather than a mobilizing force that effected the masses. It would reach this latter stage only after the Second World War. While the post First World War Zog period certainly contributed to the process by breaking down some of the internal barriers, it was the communist regime which consolidated the forging of an Albanian nation with its polices of forced conformity, social mobilization and control, and state of siege nationalism.

30 Nicola Guy, The Birth of Albania: Ethnic Nationalism, the Great Powers of World War I and the Emergence of Albanian Independence, (London: I.B. Tauris, 2012), p. 245. 


\section{$* * *$}

Bernd J. Fischer is professor of Balkan history in the Department of History at Indiana University, Fort Wayne and a foreign member of the Albanian Academy of Sciences. He is the author of a number of books, translated into Albanian and other languages, among them King Zog and the Struggle for Stability in Albania (1984, reprint 2012), Albania at War, 1939-1945 (1999), Albanian Identities, History and Myth (co-editor and co-author, 2002), Balkan Strongmen: Dictators and Authoritarian Rulers of Southeastern Europe (editor and co-author, 2007) and Albania 19431945, A View Through Western Documents (2012). He is also the author of over 10 book chapters and some 30 articles published in the United States and multiple European countries. In addition he is a frequent contributor to national and international media including the New York Times, the Voice of America, and the BBC World Service. 